\title{
POLY(TRIMETHYLENE CARBONATE) AND POLY(D,L-LACTIC ACID) MODIFY HUMAN DENDRITIC CELL RESPONSES TO STAPHYLOCOCCI BUT DO NOT AFFECT Th1 AND Th2 CELL DEVELOPMENT
}

\author{
P.P.S. Balraadjsing ${ }^{1}$, E.C. de Jong ${ }^{2,3}$, D.W. Grijpma ${ }^{4,5}$, M.W.T. Tanck ${ }^{6}$ and S.A.J. Zaat ${ }^{1, *}$ \\ ${ }^{1}$ Department of Medical Microbiology, Amsterdam Infection and Immunity Institute, \\ Academic Medical Centre, University of Amsterdam, 1105 AZ, Amsterdam, the Netherlands \\ ${ }^{2}$ Department of Cell Biology and Histology, Academic Medical Centre, University of Amsterdam, \\ 1105 AZ, Amsterdam, the Netherlands \\ ${ }^{3}$ Department Experimental Immunology, Academic Medical Centre, University of Amsterdam, \\ 1105 AZ, Amsterdam, the Netherlands \\ ${ }^{4}$ Institute for Biomedical Technology and Technical Medicine (MIRA), Department of Biomaterials \\ Science and Technology, Faculty of Science and Technology, University of Twente, \\ 7500 AE, Enschede, the Netherlands \\ ${ }^{5}$ Department of Biomedical Engineering, University Medical Centre Groningen and University \\ of Groningen, W.J. Kolff Institute, 9713 AV, Groningen, the Netherlands \\ ${ }^{6}$ Department Clinical Epidemiology, Biostatistics and Bioinformatics, Academic Medical Centre, \\ University of Amsterdam, 1105 AZ, Amsterdam, the Netherlands
}

\begin{abstract}
Biomaterial-associated infections (BAIs) are frequent complications in the use of medical devices (biomaterials) correlated with considerable patient discomfort and high treatment costs. The presence of a biomaterial in the host causes derangement of local immune responses increasing susceptibility to infection. Dendritic cells (DCs) have an important role in directing the nature of immune responses by activating and controlling $\mathrm{CD}^{+} \mathrm{T}$ helper (Th) cell responses. To assess the immunomodulatory effect of the combined presence of biomaterials and Staphylococcus aureus (S. aureus) or Staphylococcus epidermidis (S. epidermidis), DC-mediated $\mathrm{T}$ cell proliferation and Th1/Th2 cell development were measured using an in vitro human cell system. Poly(trimethylene carbonate) (PTMC) and poly(D,L-lactic acid) (PDLLA) modified the production of the DC pro-inflammatory cytokines TNF- $\alpha$, IL-6 and IL-23 in response to S. aureus and S. epidermidis. However, this modified cytokine production did not cause differences in Th1/Th2 cell polarisation, showing a Th1 cell predominance. In the absence of staphylococci, neither of the biomaterials induced DC-mediated T cell proliferation or Th1/Th2 cell polarisation. Moreover, either in the absence or presence of the biomaterials, $S$. aureus was a more potent inducer of DC cytokine secretion, T cell proliferation and Th1 cell development than S. epidermidis. In conclusion, although PTMC and PDLLA modulated DC cytokine responses to staphylococci, this did not alter the resulting Th cell development. This result suggested that, in this human cell model, Th1/Th2 cell responses were mainly determined by the species of bacteria and that PTMC or PDLLA did not detectably influence these responses.
\end{abstract}

Keywords: Biomaterial-associated infection, Staphylococcus aureus, Staphylococcus epidermidis, dendritic cell, $\mathrm{T}$ cell, immune response.

*Address for correspondence: S.A.J. Zaat, Department of Medical Microbiology, Amsterdam Infection and Immunity Institute, Academic Medical Centre, University of Amsterdam, Meibergdreef 15, 1105 AZ, Amsterdam, the Netherlands.

Telephone: +31 205664863 Email: s.a.zaat@amc.uva.nl

Copyright policy: This article is distributed in accordance with Creative Commons Attribution Licence (http://creativecommons.org/licenses/by-sa/4.0/).

\section{Introduction}

Bacterial infections are a frequent complication when using medical devices (biomaterials) and they are associated with considerable morbidity and mortality and high hospital costs. These so-called biomaterialassociated infections (BAIs) are most often caused by staphylococci, in particular by the more virulent 
Staphylococcus aureus (S. aureus) and the more benign Staphylococcus epidermidis (S. epidermidis) (Gandelman et al., 2007; Zimmerli et al., 2004). S. aureus produces numerous virulence factors, such as toxins and enzymes, and causes more acute implant infections when compared to $S$. epidermidis, which causes more subacute or even chronic implant infections (Vuong and Otto, 2002). BAIs are generally difficult to treat because bacteria can colonise the implanted biomaterial by forming a biofilm. In biofilms, bacteria are often more resistant to antibiotics and host defence mechanisms, when compared to their planktonic counterparts (Donlan and Costerton, 2002; Stewart and Costerton, 2001). However, infecting bacteria not only reside in biofilms on the biomaterial surface, but also in tissue surrounding the implant and even inside phagocytic cells (Boelens et al., 2000a; Broekhuizen et al., 2008) and osteoblasts (Bosse et al., 2005). In a mouse experimental BAI model, macrophages in the tissue surrounding a subcutaneously implanted poly(vinylpyrrolidone)coated catheter of silicon elastomer or polyamide show intracellular persistence of $S$. epidermidis, whereas bacterial challenge of mice without an implant leads to efficient bacterial clearance (Boelens et al., 2000a; Broekhuizen et al., 2010). Impairment of innate immune cell functions in BAIs is not restricted to macrophages nor to one type of biomaterial. In addition to macrophages, polymorphonuclear neutrophils (PMNs), harvested from subcutaneously implanted Teflon ${ }^{\mathrm{TM}}$ tissue cages, have a decreased bactericidal activity against $S$. aureus (Zimmerli et al., 1984; Zimmerli and Sendi, 2011). Moreover, monocytes show decreased expression of major histocompatibility complex II (MHC-II) molecules in presence of poly(ethylene terephthalate) colonised with S. epidermidis (Henke et al., 1997), which is expected to reduce antigen presentation and ensuing $\mathrm{T}$ cell activation. It is apparent that the local condition of the tissue surrounding an infected biomaterial provides signals that may impair proper innate immune cell function.

Currently, most of the studies investigating staphylococci-induced host immune responses in BAIs focus on innate immunity (Zimmerli and Sendi, 2011), whereas activation and regulation of adaptive immunity receive relatively little attention. Although innate immune cells are important in the first line defence against bacteria, they often need help from adaptive CD4 ${ }^{+} \mathrm{T}$ helper (Th) cells. Th cells boost the microbicidal functions of a variety of innate immune cells, such as macrophages. In human patients, plenty of $\mathrm{T}$ cells are found at sites of biomaterial infection (Dapunt et al., 2014; Wagner et al., 2006); however, their exact role in BAIs is not known. CD4 ${ }^{+}$Th cell activation and regulation is orchestrated by dendritic cells (DCs). Therefore, to understand the role of Th cells in BAIs, it is critical to study activation and regulation of Th cells by DCs.

Inadequate Th cell activation may be responsible for compromised immune defences around infected biomaterials. Protective adaptive immunity against staphylococci in humans, even in the absence of biomaterials, is not completely understood. Th1 and Th17 cell responses are thought to be protective against S. aureus infection (Brown et al., 2015; Milner et al., 2008), but not much is known about protective human Th cell responses against $S$. epidermidis infection. To the best of our knowledge, human Th cell responses to staphylococci in the presence of a biomaterial have not been characterised. However, in mice, Th1 and Th17 cell responses appear to play a role in BAIs. Treatment of mice with the Th1 cell effector cytokine interferon gamma (IFN- $\gamma$ ) reduces susceptibility to $S$. epidermidis infection around subcutaneously implanted catheter segments (Boelens et al., 2000b), presumably since IFN- $\gamma$ enhances the microbicidal activity of phagocytes (Kubica et al., 2008; Smith et al., 2010). This indicates that poor Th1 cell development in BAIs may be responsible for inefficient $S$. epidermidis clearance. On the other hand, Th1/Th17 cell responses seem ineffective in the clearance of $S$. aureus murine prostheticimplant infections, whereas Th2 and regulatory $\mathrm{T}$ cell responses protect from the inflammation (Prabhakara et al., 2011; Rochford et al., 2016). These studies indicate that, in mice, the combination of staphylococci and a biomaterial can influence Th cell responses in favour of staphylococcal infection. In this respect, knowledge about the regulation of Th cell subset development in a BAI is important to understand the balance between protective and harmful Th cell responses.

The aim of this study was to investigate the possible immunomodulatory effect of biomaterials on S. aureus- and S. epidermidis-induced immune responses, by measuring human DC and $\mathrm{T}$ cell activation. Human DC activation and, subsequently, DC-mediated $\mathrm{T}$ cell proliferation and Th1/Th2 cell polarisation induced by $S$. aureus or $S$. epidermidis in presence of poly(D,L-lactic acid) (PDLLA) and poly(trimethylene carbonate) (PTMC) were studied. PDLLA and PTMC are biodegradable and biocompatible materials provoking a normal foreign body response, as commonly seen after implantation of sterile biodegradable polymers (Pego et al., 2003; Schakenraad et al., 1989). PTMC may be slightly more immunoreactive, since it supports good immune cell adhesion (Bat et al., 2009; Shokouhi et al., 2010). Our results showed that both PTMC and PDLLA influenced DC cytokine production in response to $S$. aureus and $S$. epidermidis, but that neither polymer influenced the staphylococcus-induced T cell proliferation nor $\mathrm{T}$ cell polarisation. In the absence of the staphylococci, neither biomaterial induced DCmediated $\mathrm{T}$ cell activation or polarisation, indicating that these materials are not immune-activating on their own in our human cell model. Furthermore, it was shown that $S$. aureus bacteria were stronger inducers of DC cytokine secretion, $\mathrm{T}$ cell proliferation and Th1 cell development than S. epidermidis, either in absence or in presence of the biomaterials. 


\section{Materials and Methods}

\section{Preparation of biomaterial films}

Biodegradable polymer films were fabricated using a compression moulding machine (Fonteijne THB008, Vlaardingen, the Netherlands). Medical grade PDLLA (inherent viscosity $0.2 \mathrm{dL} / \mathrm{g}$, used without further purification; Purac Biochem, Gorkum, the Netherlands) was moulded using a $200 \mu \mathrm{m}$-thick stainless-steel mould at approximately $150{ }^{\circ} \mathrm{C}$ and $250 \mathrm{kN} / \mathrm{cm}^{2}$ load-pressure. Medical grade PTMC (molecular weight $250 \mathrm{~kg} / \mathrm{mol}$, used without further purification; Foryou Medical, P.R., Huizhou, China) was moulded using a $500 \mu \mathrm{m}$-thick stainlesssteel mould at approximately $160{ }^{\circ} \mathrm{C}$ and $350 \mathrm{kN} /$ $\mathrm{cm}^{2}$ load-pressure. The PTMC film was exposed to $25 \mathrm{kGy}$ gamma irradiation from a ${ }^{60} \mathrm{Co}$ source (Synergy Health, Ede, the Netherlands) in a nitrogen atmosphere in order to crosslink the polymer. Scanning electron microscopy imaging showed that the surfaces of PDLLA and PTMC films had a smooth appearance without pores (data not shown). Disks with a diameter of $15 \mathrm{~mm}$, to fit in the wells of 24-wells cell culture plates, were punched out of the PDLLA and PTMC films using a hole punch. The disks were disinfected with $70 \%$ aqueous isopropanol for $15 \mathrm{~min}$ followed by washing in sterile phosphate-buffered saline (PBS). The procedure was repeated three times. After the last wash, disks were immersed in sterile PBS and stored at room temperature until the experiment was performed on the next day.

\section{Bacteria}

S. aureus strain ATCC 49230 and S. epidermidis strain RP62a (ATCC 35984; both from ATCC; Manassas, VA, USA), both biofilm-producing strains isolated from patients with a BAI (Beenken et al., 2003; Christensen et al., 1985), were used in the present study. Prior to each experiment, the bacteria were cultured at $37^{\circ} \mathrm{C}$ under agitation in tryptic soy broth (TSB; BD Difco, Etten-Leur, the Netherlands) until the logarithmic growth phase. The viable bacteria were harvested by centrifugation and resuspended to the desired concentrations in Iscove's modified Dulbecco's medium (IMDM, Lonza, Walkersville, MD, USA) containing $10 \%$ foetal calf serum (FCS, Thermo Fisher Scientific Inc., Logan, UT, USA).

\section{Generation and stimulation of DCs}

Immature DCs (iDCs) were generated and cultured as previously described (de Jong et al., 2002; Sallusto and Lanzavecchia, 1994). In brief, monocytes were isolated from heparinised blood of healthy human donors by density gradient centrifugation on Lymphoprep ${ }^{\mathrm{TM}}$ (Nycomed, Oslo, Norway) and Percoll $^{\circledR}$ (GE Healthcare, Uppsala, Finland) density gradient media. Isolated monocytes $\left(4 \times 10^{5}\right.$ cells/well $)$ were cultured in 24-well cell culture plates in IMDM (Gibco, Grand Island, NE, USA) supplemented with $5 \%$ FCS, $86 \mu \mathrm{g} / \mathrm{mL}$ gentamicin (Duchefa,
Biochemie B.V., Haarlem, the Netherlands), 500 U/ $\mathrm{mL}$ recombinant human granulocyte-macrophage colony-stimulating factor (GM-CSF; ScheringPlough, Whitehouse Station, NJ, USA) and $10 \mathrm{IU} / \mathrm{mL}$ recombinant human IL-4 (Miltenyi Biotec, Bergisch Gladbach, Germany). After $3 \mathrm{~d}$, half of the cell culture medium was replaced with fresh medium. After $6 \mathrm{~d}$, monocytes were fully differentiated into iDCs, as confirmed by the loss of monocyte marker CD14. On day 6, iDCs were resuspended (approximately $1 \times 10^{5}$ cells/well) and stimulated for $48 \mathrm{~h}$ with S. aureus or $S$. epidermidis bacteria $\left[1 \times 10^{7}\right.$ colony forming unit (CFU)/well] in the absence or presence of PDLLA or PTMC discs. To prevent bacterial overgrowth, $10 \mu \mathrm{g} / \mathrm{mL}$ moxifloxacin (Avelox, Bayer Schering Pharma, Mijdrecht, the Netherlands) was added to all conditions tested. The ratio between iDCs and staphylococci $(1: 100)$ used in these co-culture experiments was based on the ratio leading to a level of DC maturation equal to that of DCs stimulated with $100 \mathrm{ng} / \mathrm{mL}$ lipopolysaccharide (from Escherichia coli 0111:B4) or $20 \mu \mathrm{g} / \mathrm{mL}$ Poly(I:C) (both purchased from Sigma-Aldrich, St. Louis, CA, USA). No major differences in DC viability nor in the proportion of apoptotic cells were observed after stimulation, as examined by flow cytometry using propidium iodide (Sigma-Aldrich) and Annexin V (BD Biosciences, San Jose, CA, USA) staining, respectively.

\section{Isolation of autologous naive $T$ cells}

To investigate the primary response of T cells, naive $\mathrm{CD}^{+} \mathrm{T}$ cells were used. Naive T cells were obtained by isolating PBMCs from the blood of healthy human donors by density gradient centrifugation on Lymphoprep ${ }^{\mathrm{TM}}$ and Percoll ${ }^{\circledR}$ density gradient media and finally by negative selection using the $\mathrm{CD}^{+} \mathrm{T}$ cell isolation MACS kit (Miltenyi Biotec) followed by CD45RO-PE (Dako, Amstelveen, the Netherlands) and magnetic anti-PE beads (Miltenyi Biotech) (van der Aar et al., 2011). The purity of the isolated naive $\mathrm{CD}^{+}\left(\mathrm{CD}^{2} 5 \mathrm{RO}^{-} \mathrm{CD} 45 \mathrm{RA}^{+}\right) \mathrm{T}$ cells was $>97 \%$, as measured by flow cytometry (Canto II, BD Biosciences).

\section{DC maturation analysis}

After $48 \mathrm{~h}$ of stimulation, DC maturation was analysed by measuring the secreted cytokines in the supernatants and the expression of cell surface molecules. Supernatants were harvested and stored at $-20{ }^{\circ} \mathrm{C}$ until the levels of the cytokines TNF- $\alpha$ (eBioscience, Logan, UT, USA), IL-10 (BD Pharmingen), IL-6 (UCytech, Utrecht, the Netherlands), IL-23 (UCytech), IL-1 $\beta$ (Endogen, Woburn, MA, USA) and IL-12p70 (UCytech) were analysed by sandwich enzyme-linked immunosorbent assays (ELISAs) (de Jong et al., 2002). The expression of cell surface molecules was analysed by flow cytometry (Canto II, BD Biosciences) after staining with fluorescent antibodies against HLA-DR, CD83 and CD86 (all purchased from BD Biosciences). For each fluorescent 
antibody, cells stained with a single fluorophore were used to correct for false positive fluorescence (data not shown). A gate, based on forward and side scatters, was set to exclude dead cells, cell debris and doublets.

\section{$\mathrm{T}$ cell proliferation}

To study autologous naive $\mathrm{CD} 4^{+} \mathrm{T}$ cell proliferation, DCs were stimulated for $48 \mathrm{~h}$ as described above, washed and co-cultured for $5 \mathrm{~d}$ with carboxyfluorescein succinimidyl ester- (CFSE; $0.5 \mu \mathrm{m}$, Life Technologies, Eugene, OR, USA) labelled autologous naive $\mathrm{CD}^{+} \mathrm{T}$ cells $\left(\mathrm{CD} 45 \mathrm{RO}^{-} \mathrm{CD} 45 \mathrm{RA}^{+}\right)$at a ratio of $1: 1\left(4 \times 10^{4}: 4 \times 10^{4}\right.$ cells $)$. T cell proliferation was determined by flow cytometry (Canto II, BD Biosciences) and quantified using FlowJo software (version 7.6.5, Tree star, Ashland, OR, USA). The division and proliferation indices were calculated. The division index indicates the average number of cell divisions for all cells in the original culture (non-dividing cells included); the proliferation index represents the average number of divisions of the responding population (non-dividing cells excluded). By definition, the value of the proliferation index is $\geq 1.0$.

\section{Th cell polarisation}

In order to study the polarisation of autologous naive $\mathrm{CD}^{+} \mathrm{T}$ cells, $1 \times 10^{5} \mathrm{iDCs}, 1 \times 10^{7} \mathrm{CFU}$ of $S$. aureus or $S$. epidermidis and $1 \times 10^{5} \mathrm{~T}$ cells were co-cultured in cell culture medium in absence or presence of the biomaterials. After approximately $4 \mathrm{~d}$, half of the medium was replaced with $\mathrm{T}$ cell culture medium consisting of IMDM (Lonza) with 10 \% FCS, $86 \mu \mathrm{g} /$ $\mathrm{mL}$ gentamicin and $20 \mathrm{U} / \mathrm{mL}$ recombinant human IL-2 (Novartis AG, Nuremberg, Germany) to promote $\mathrm{T}$ cell survival and proliferation. Every $2 \mathrm{~d}$, half of the medium was replaced with fresh $\mathrm{T}$ cell culture medium and cell suspensions were diluted, if necessary, until T cell cultures were resting (approximately by day 13 ). Resting $\mathrm{CD}^{+} \mathrm{T}$ cells were re-stimulated for $5 \mathrm{~h}$ with $100 \mathrm{ng} / \mathrm{mL}$ phorbol myristate acetate (PMA), $1 \mu \mathrm{g} / \mathrm{mL}$ ionomycin and $10 \mu \mathrm{g} / \mathrm{mL}$ brefeldin A (BFA) (all purchased from Sigma-Aldrich) to allow detection of intracellular production of the Th1 and Th2 cell signature cytokines IFN- $\gamma$ and IL-4, respectively. CD4 ${ }^{+} \mathrm{T}$ cells were analysed by flow cytometry after fixation with $3.7 \%$ formaldehyde (Sigma-Aldrich) and permeabilisation with $0.5 \%$ saponin (Calbiochem, Darmstadt, Germany) followed by intracellular staining with anti-IL-4 and anti-IFN- $\gamma$ (both from BD Bioscience) antibodies for $30 \mathrm{~min}$ (de Jong et al., 2002). For both fluorescent antibodies, cells stained with a single fluorophore were used to allow for proper gating of IFN- $\gamma$ - and IL-4-positive cells (data not shown).

\section{Statistical analysis}

The data were analysed using linear mixed models (LMM) (covariance type: compound symmetry) on rank-transformed data with donor as covariate, followed by the post-hoc Wilcoxon signed ranked test for pairwise comparisons. The immunomodulatory effect of the combination of biomaterials and staphylococci was measured by assessing markers related to four different outcome groups: DC maturation marker expression, DC cytokine production, Th cell polarisation and $\mathrm{T}$ cell proliferation. The linear mixed model was considered to be statistically significant at $p \leq 0.0125$ (adjusted for four outcome groups). The Wilcoxon signed ranked test was considered to be statistically significant at $p \leq 0.05$. Missing values in our data set resulted in unequal number of donors per tested condition. The LMM produces valid estimates even in the case of missing values. Analysis of the more restricted data set only using donors with a complete set of conditions confirmed the validity of our approach since the statistical interpretation of the results remained the same as compared to the results using the total data set with all donors. Statistical analyses were performed using IBM SPSS Statistics software version 24 (IBM Corp., Armonk, NY, USA).

\section{Results}

\section{Minimal influence of PDLLA and PTMC on Staphylococcus-induced DC maturation marker expression}

DC maturation, characterised by an increase in the expression of the co-stimulatory molecules CD86 and CD83 and of HLA-DR, is central to the induction of adaptive T cell responses. Exposure of DCs to PDLLA or PTMC did not affect these markers, whereas DCs exposed to $S$. aureus or S. epidermidis expressed significantly higher levels of the co-stimulatory molecules and HLA-DR than unstimulated DCs (Fig. 1a,b). When DCs were exposed to biomaterials and bacteria combined, the presence of PDLLA did not affect the $S$. aureus- or $S$. epidermidis-induced DC marker expression (Fig. 1a,c). The presence of PTMC caused a small but significant reduction of the S. epidermidis-induced CD86 expression (Fig. 1a,c). Interestingly, exposure to the combination of PTMC and staphylococci caused slightly lower levels of CD86 expression as compared with the combination of PDLLA and staphylococci (Fig. 1a), indicating that the two biomaterials differentially affected CD86 expression in presence of staphylococci. Taken together, PDLLA and PTMC had no, or only minor, effects on S. aureus- and S. epidermidis-induced DC maturation marker expression.

\section{DC cytokine secretion in response to the combination of staphylococci and biomaterials} In order to assess the potential of the DCs to polarise Th cells, DC cytokine production was studied. IL-1 $\beta$ was undetectable in all cases (data not shown). In incubations with only biomaterials, DCs exposed to PDLLA or PTMC did not produce detectable levels of 
a
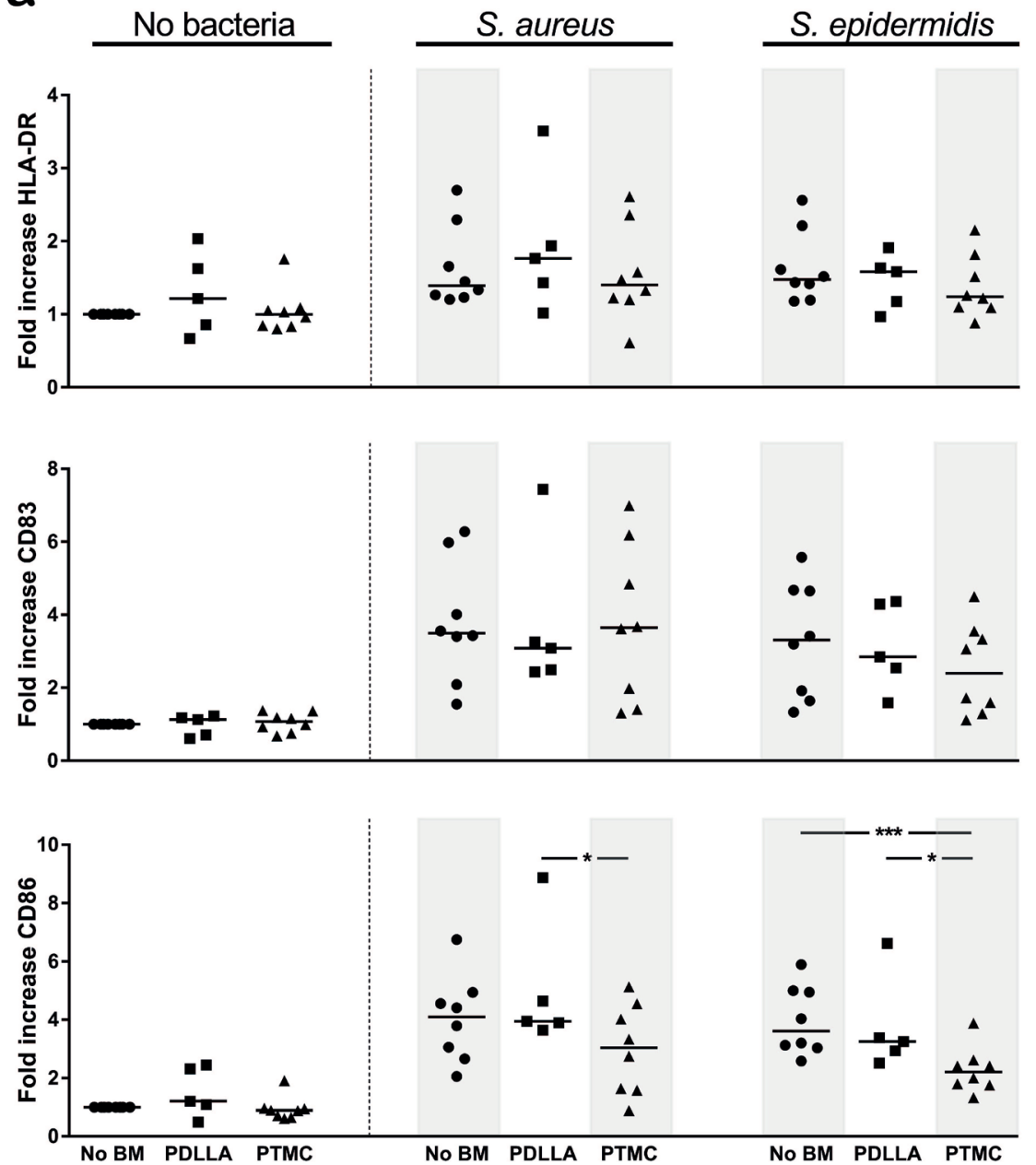

b
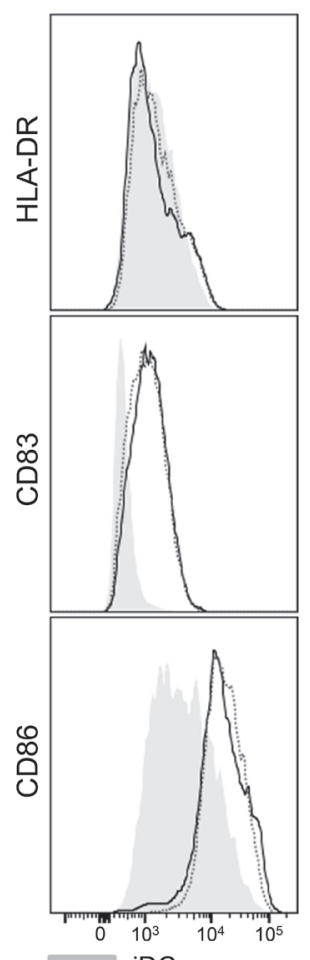

iDC

S. epidermidis

S. aureus
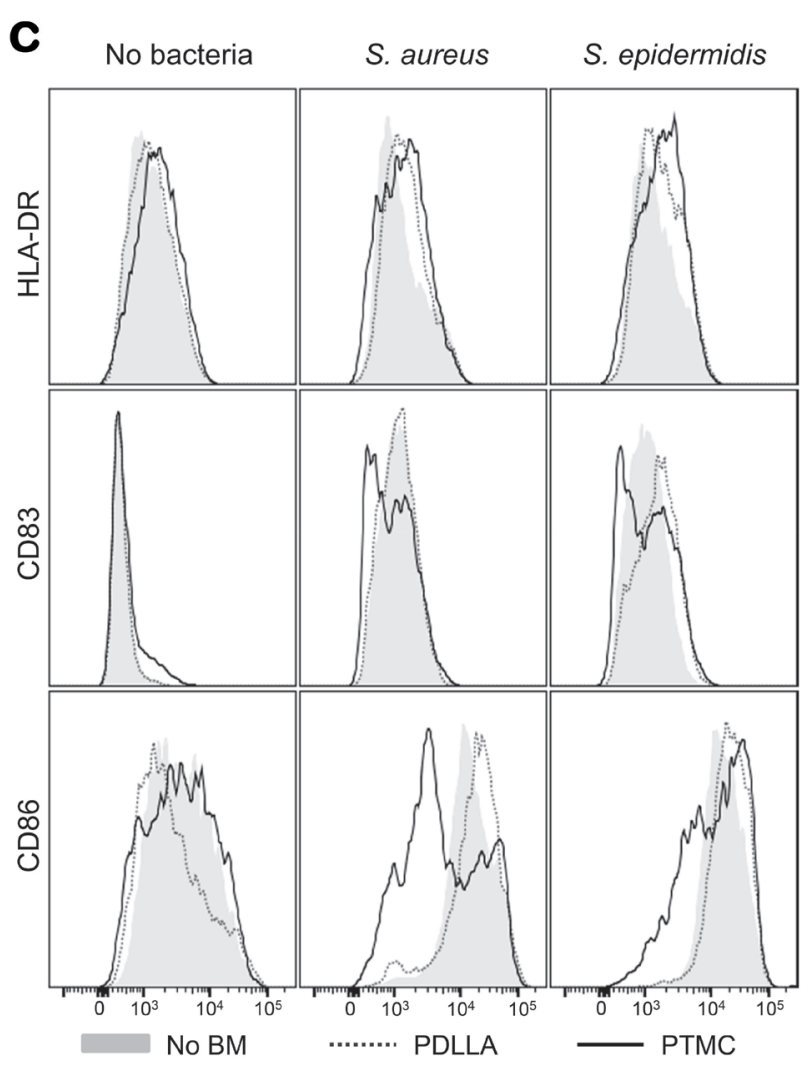

Fig. 1. Combined effect of biomaterials and staphylococci on DC maturation marker expression. (a) Fold difference of geometric mean fluorescence intensity of HLA-DR, CD83 and CD86 of stimulated relative to unstimulated DCs; no bacteria and no biomaterial (BM). Each dot represents one donor. The horizontal line represents the median value per group. Exposure to $S$. aureus or S. epidermidis significantly enhanced the expression of all three DC maturation markers, when compared to unstimulated DCs (all $p \leq 0.01$, significance not indicated in the figure). ${ }^{*} p \leq 0.05,{ }^{* * *} p \leq 0.001$. $(\mathbf{b}, \mathbf{c})$ Cell surface expression of HLA-DR, CD83 and CD86 ( $\log _{10}$ fluorescence intensity) on DCs. Data of 1 representative experiment out of 5-8 experiments with cells from different donors. (b) Expression on unstimulated (filled), $S$. aureus- (solid) or S. epidermidis(dashed) stimulated DCs. (c) Expression on unstimulated DCs exposed to biomaterials in absence (left) or presence of $S$. aureus (middle) or $S$. epidermidis (right). 
any of the cytokines analysed (Fig. 2). In incubations with only bacteria, DCs exposed to $S$. aureus secreted significantly higher levels of all tested cytokines than unstimulated DCs (Fig. 2). DCs exposed to $S$. epidermidis secreted low but significantly higher levels of TNF- $\alpha$, IL-10, IL-6 and IL-23 than unstimulated DCs (Fig. 2). Interestingly, DCs exposed to $S$. epidermidis did not produce detectable levels of Th1cell-polarising cytokine IL-12p70 (Fig. 2e), suggesting that these DCs would not drive Th1 cell development. a

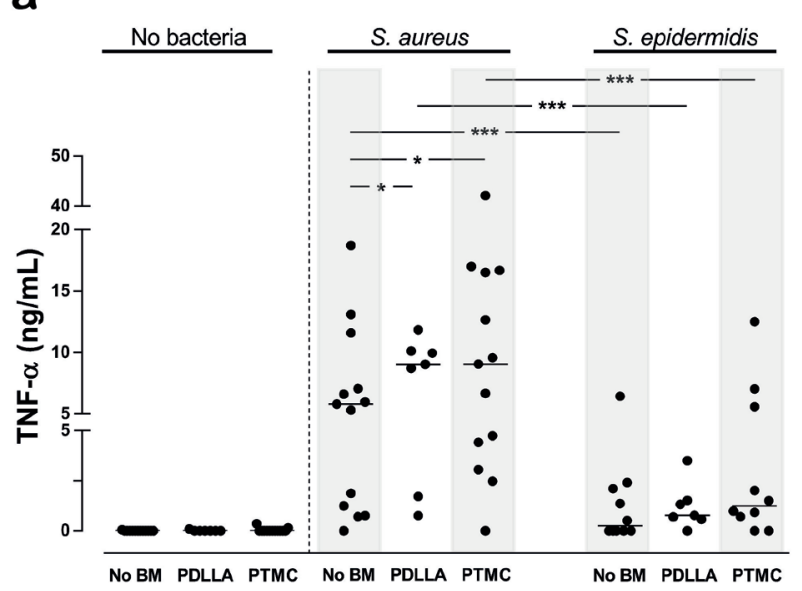

C

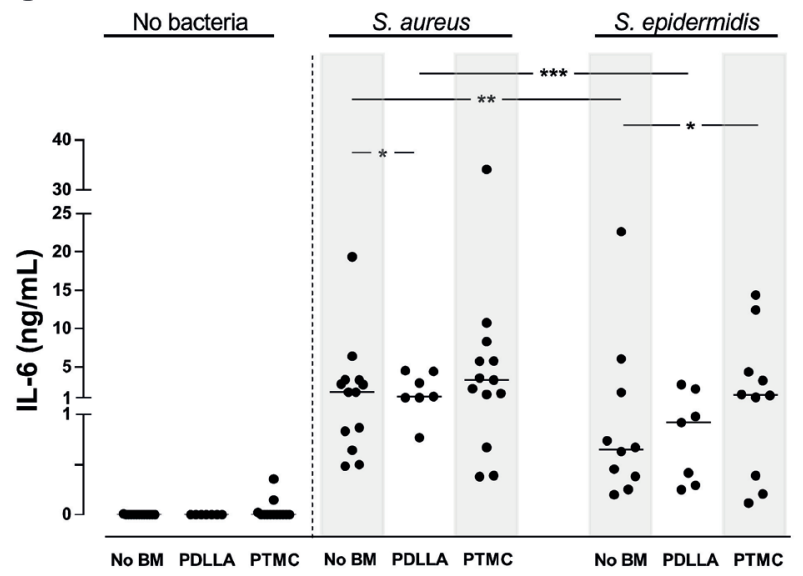

b

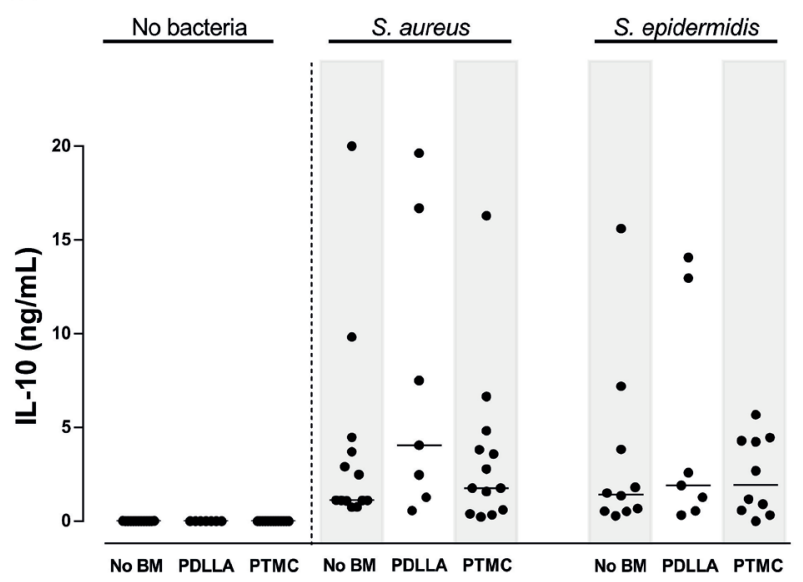

d

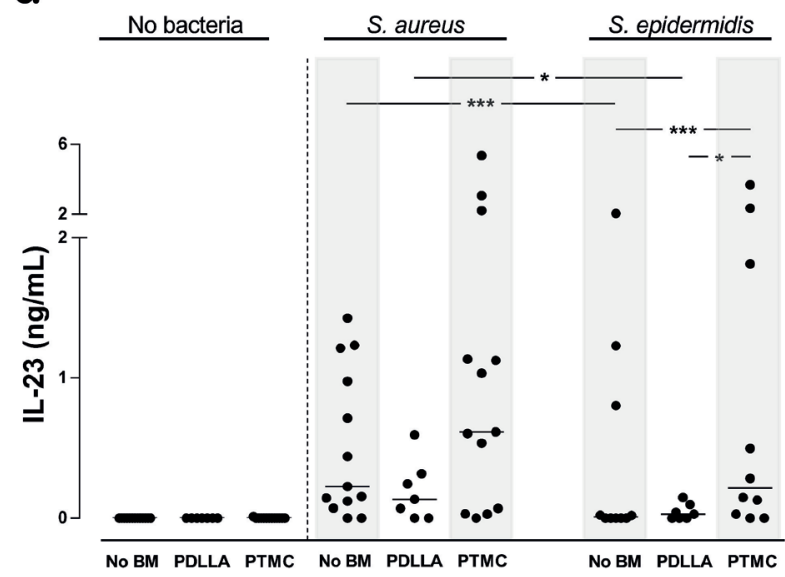

e

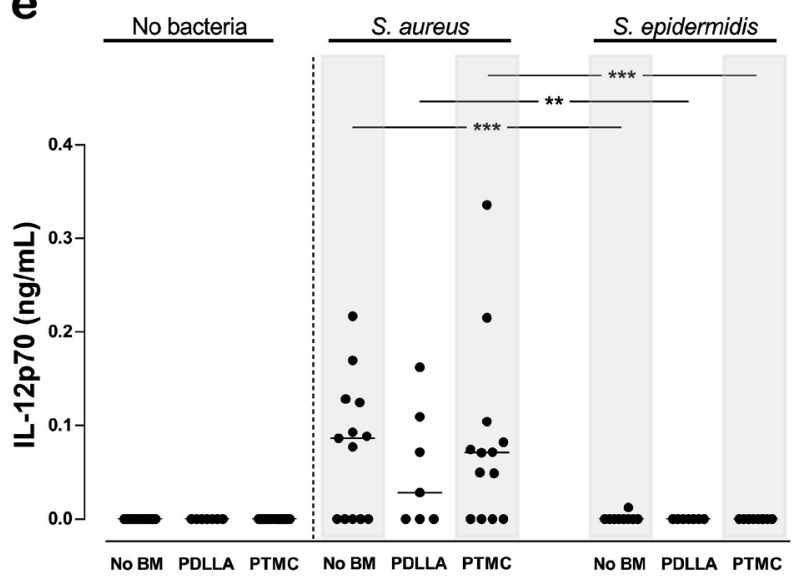

Fig. 2. (a-e) Production of cytokines by DCs upon exposure to staphylococci and/or biomaterials. DC cytokine concentrations determined by ELISA of 7-13 independent experiments with cells from different donors, performed in triplicate. Unstimulated DCs (no bacteria and no BM) and DCs exposed to PDLLA and PTMC did not produce detectable levels of any of the tested cytokines. Each dot represents the average cytokine concentration for a single donor. The horizontal line represents the median value per group. Compared to unstimulated DCs, DCs exposed to $S$. aureus and S. epidermidis induced higher levels of all tested cytokines (all $p \leq 0.001$, significance not indicated in the figure). (a) TNF- $\alpha$; (b) IL-10; (c) IL-6; (d) IL-23; (e) IL-12p70. * $p \leq 0.05,{ }^{* *} p \leq 0.01,{ }^{* * *} p \leq 0.001$. 
In combined exposure of DCs to biomaterials and bacteria, PDLLA slightly decreased the S. aureusinduced secretion of IL- 6 and slightly enhanced the $S$. aureus-induced secretion of TNF- $\alpha$ (Fig. 2a,c). PTMC enhanced the $S$. aureus-induced secretion of TNF- $\alpha$ (Fig. 2a) and the S. epidermidis-induced secretion of IL-6 and IL-23 (Fig. 2c,d). Notably, the staphylococcusinduced secretion of IL-10 and IL-12p70 was not altered by presence of either of the biomaterials (Fig. $2 \mathbf{b}, \mathbf{e})$.
Of all cytokines tested, only IL-23 secretion was differently affected by PDLLA and PTMC in combination with S. epidermidis (Fig. 2d), indicating that differences in biomaterial characteristics minimally influenced the DC cytokine response. In contrast, $S$. aureus and S. epidermidis differently affected DC cytokine secretion. DCs exposed to $S$. aureus secreted higher levels of TNF- $\alpha$, IL-6, IL-23 and IL-12p70 than DCs exposed to S. epidermidis (Fig. 2). Moreover, in combination with PDLLA and

a
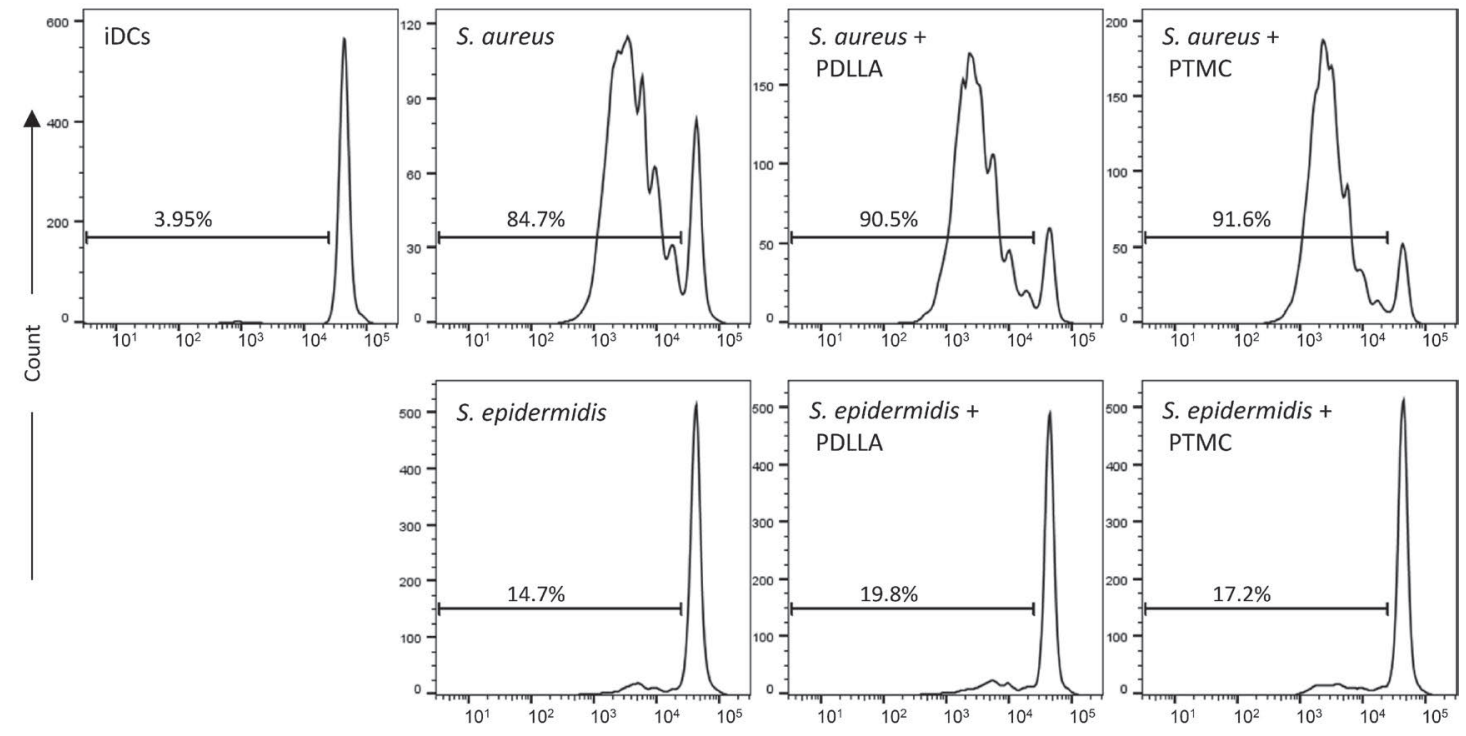

b

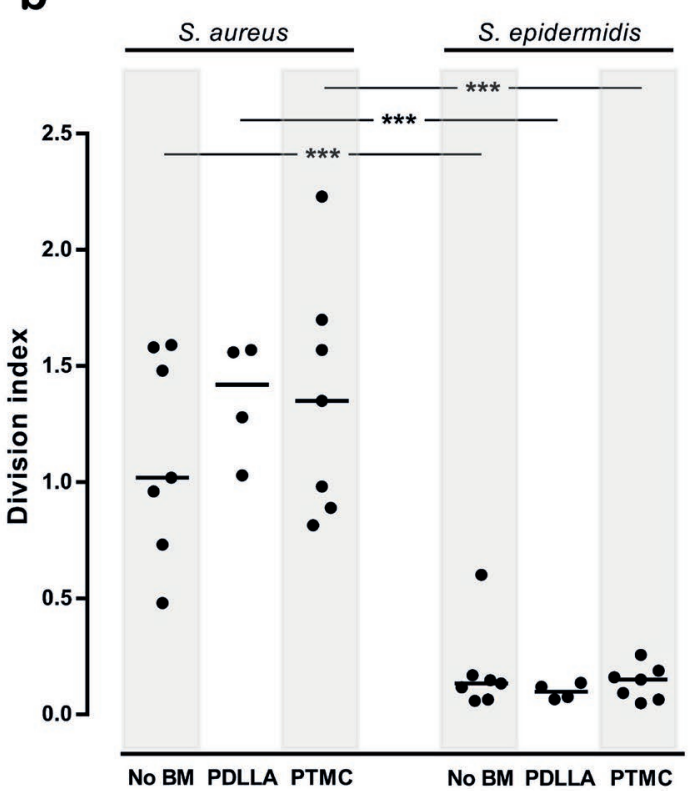

C

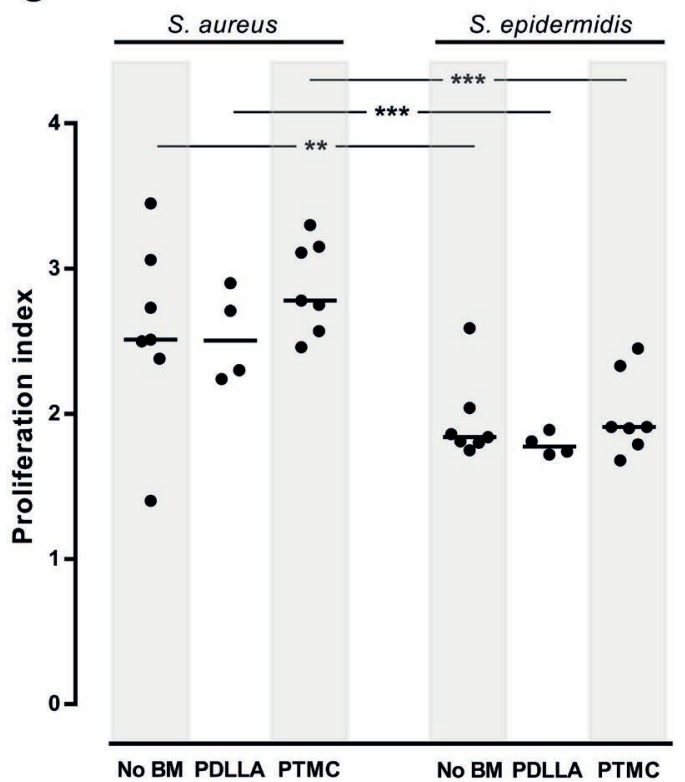

Fig. 3. Proliferation of antigen-specific naive CD4+ T cells after $5 \mathrm{~d}$ of co-culture with staphylococci- and/ or biomaterial-exposed DCs. (a) CFSE profiles of T cells proliferation. Data of 1 representative experiment out of 4 or 7 experiments with cells from different donors $\left(\log _{10}\right.$ fluorescence intensity). The percentage of T cells proliferation is indicated. DCs exposed to only PDLLA or PTMC induced T cell proliferation similar to iDCs (data not shown). (b) Division index and (c) proliferation index per stimulus. Each dot represents one donor tested in an individual experiment. The horizontal line represents the median value. Data of 4 or 7 independent experiments. ${ }^{* *} p \leq 0.01,{ }^{* * *} p \leq 0.001$. 
a

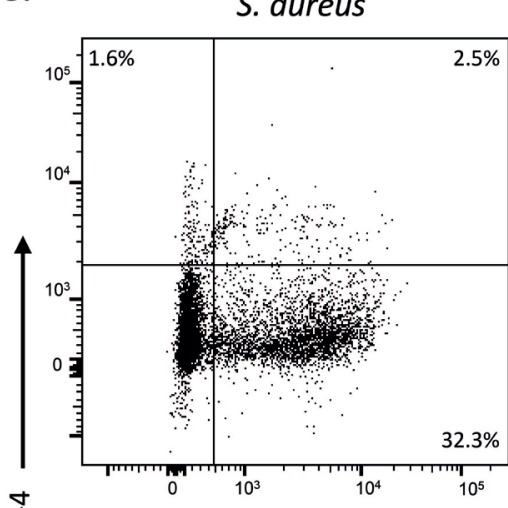

$\stackrel{+}{\stackrel{9}{+}}$

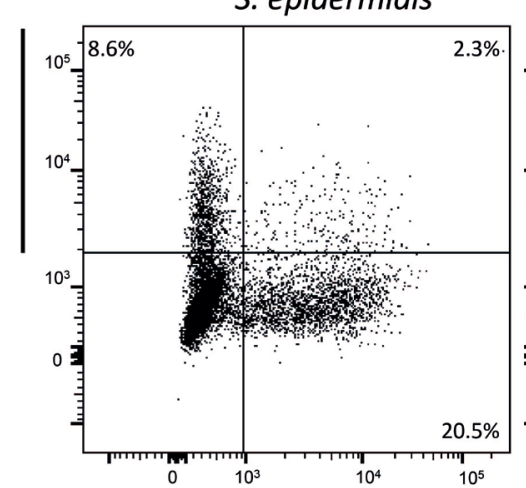

S. aureus + PDLLA

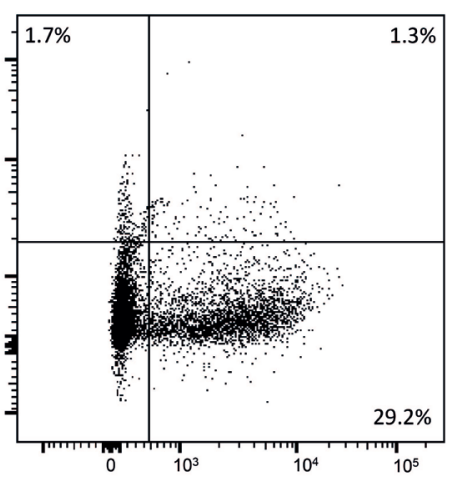

S. epidermidis + PDLLA

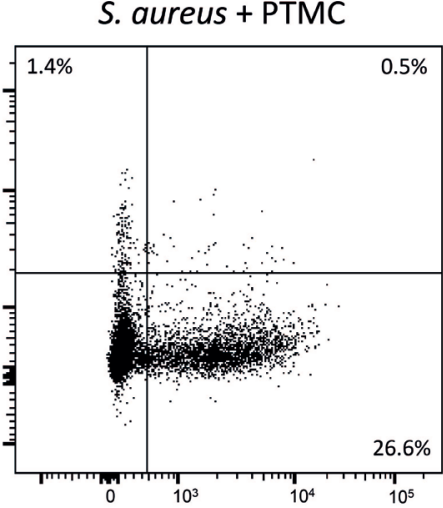

S. epidermidis + PTMC
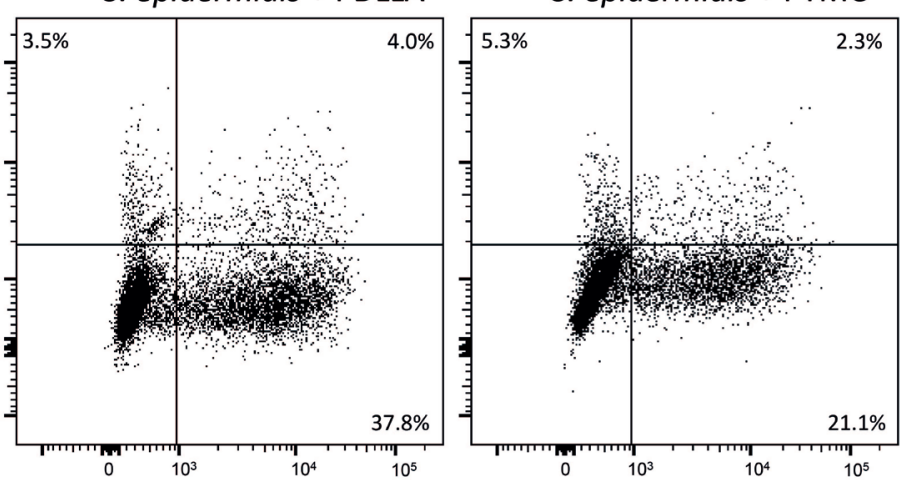

IFN- $p$

b

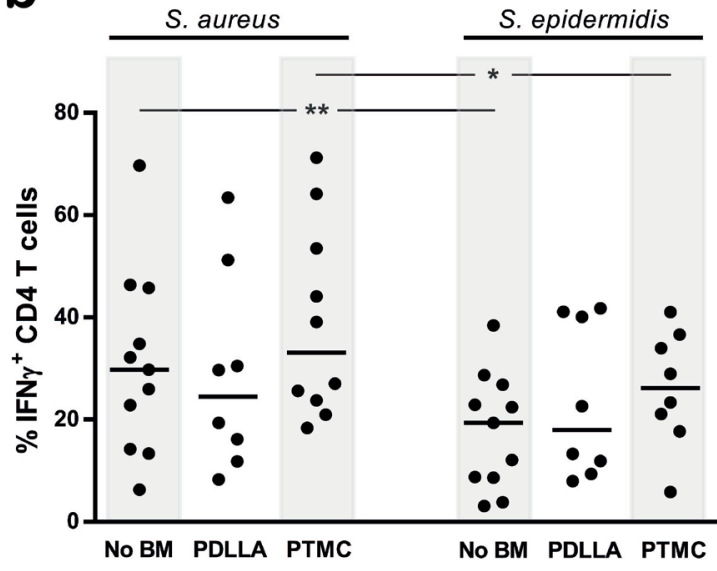

S. aureus

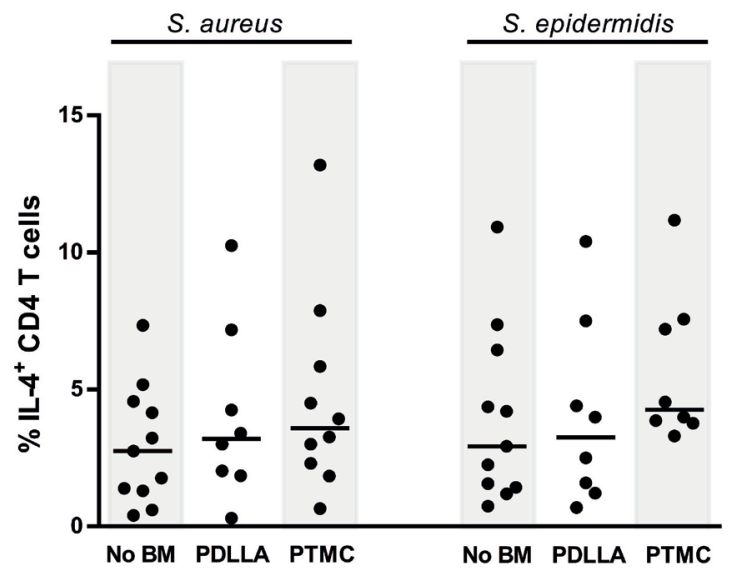

Fig. 4. Th1 and Th2 cell polarisation of antigen-specific naive CD4+ T cells induced by DCs exposed to staphylococci in combination with biomaterials. Th1 or Th2 cell polarisation of resting T cells was determined by measuring intracellular levels of IFN- $\gamma$ and IL-4, respectively. (a) FACS dot plots of 1 representative experiment out of 8 or 11 experiments with cells from different donors. Intracellular expression of IFN- $\gamma$ and IL-4 ( $\log _{10}$ fluorescence intensity). (b) Percentages of IFN- $\gamma$ - or IL-4-expressing T cells. The horizontal line represents the median value. Data of 8 or 11 independent experiments. ${ }^{*} p \leq 0.05$, ** $p \leq 0.01$. 
PTMC, S. aureus induced higher levels of TNF- $\alpha$, IL-6, IL-23 and IL-12p70 secretion and of TNF- $\alpha$ and IL-12p70 secretion, respectively, compared with S. epidermidis (Fig. 2). Taken together, these results showed that simultaneous exposure to biomaterials and staphylococci slightly but significantly modified DC secretion of pro-inflammatory cytokines relative to the secretion induced by exposure to the bacteria alone. These changes in cytokine levels might affect DC-induced Th cell polarisation. Moreover, S. aureus bacteria proved to be more potent inducers of DC cytokine secretion than S. epidermidis bacteria.

\section{Antigen-specific $\mathrm{T}$ cell proliferation in response to staphylococci was not altered by PDLLA and PTMC}

Whether the DCs matured in presence of staphylococci and biomaterial were functionally active was determined by analysing their ability to induce antigen-specific naive $\mathrm{CD}^{+} \mathrm{T}$ cell proliferation. DCs exposed to only PDLLA or PTMC did not support antigen-specific T cell proliferation (data not shown), similar to iDCs (Fig. 3a). DCs incubated with S. aureus, either in absence or presence of the biomaterials, were potent inducers of $\mathrm{T}$ cell proliferation, as judged based on the CFSE profiles of the T cells (Fig. 3a). In contrast, DCs exposed to $S$. epidermidis, either in absence or in presence of the biomaterials, induced only low levels of $\mathrm{T}$ cell proliferation (Fig. 3a). Analysis of the CFSE profiles indicated that the division index (the number of cell divisions of all $\mathrm{T}$ cells) after stimulation with $S$. aureus had a median value of 1.02 (Fig. 3b). Combined exposure to $S$. aureus and either PDLLA or PTMC did not significantly increase T cell proliferation, with division index values of 1.42 and 1.35, respectively (Fig. 3 b). Exposure to S. aureus or S. aureus + PDLLA induced T cell proliferation with almost identical median proliferation index values of 2.51 and 2.50, respectively, reflecting the average number of divisions of the responding T cells (Fig. 3c). S. aureus in combination with PTMC induced T cell proliferation with a proliferation index value of 2.78, which was not significantly different from the value of T cells activated by S. aureus alone (Fig. 3c). The combination of $S$. epidermidis and PDLLA or PTMC caused a low level of T cell proliferation, with division index values of 0.10 and 0.15 , respectively, and proliferation index values of 1.78 and 1.91, respectively. These values were not statistically different from S. epidermidis-induced division and proliferation index values (Fig. $3 \mathbf{b}, \mathbf{c}$ ). Our results indicated that the presence of the biomaterials did not influence the S. aureus- or S. epidermidis-induced T cell proliferation. Strikingly, S. aureus and $S$. epidermidis induced comparable expression of DC maturation markers, but DCs exposed to $S$. aureus induced significantly more $\mathrm{T}$ cell proliferation than S. epidermidis-exposed DCs, in absence as well as in presence of the biomaterials (Fig. 3b,c).

Together, these data indicated that PDLLA and PTMC did not influence Staphylococcus-induced T cell proliferation, but a clear difference was observed between $S$. aureus- and S. epidermidis-induced T cell proliferation.

\section{PDLLA and PTMC did not alter Staphylococcus- induced Th1 or Th2 cell polarisation}

The combination of $S$. aureus or S. epidermidis with the biomaterials influenced the production of different levels of TNF- $\alpha$, IL-6 and IL-23 from DCs (Fig. 2), suggesting that Th cell polarisation directed by these DCs might be different as well. To determine Th cell polarisation, intracellular levels of IFN- $\gamma$ and IL-4, as markers for Th1 and Th2 cells, respectively, were analysed. Since unstimulated DCs (iDCs) and DCs exposed to PDLLA and PTMC did not induce Th cell proliferation, no polarisation could be recorded. In accordance with earlier studies (van Beelen et al., 2007), S. aureus predominantly induced Th1 cells from naive $\mathrm{T}$ cell precursors and only low levels of Th2 cells (Fig. 4a,b). DCs exposed to S. epidermidis secreted undetectable levels of IL-12p70 (Fig. 2e) and induced low levels of $\mathrm{T}$ cell proliferation (Fig. 3). The T cells, which proliferated upon S. epidermidis exposure, were predominantly Th1 cells. Combining S. aureus or S. epidermidis with either of the biomaterials did not significantly change the Th1/Th2 polarisation relative to the effect of $S$. aureus or $S$. epidermidis alone (Fig. 4b). In line with the higher induction of DC cytokines, $S$. aureus was also a more potent inducer of Th1 cell development than S. epidermidis (Fig. 4b) Collectively, these data indicated that neither of the biomaterials affected $S$. aureus- or S. epidermidisinduced Th1 and Th2 cell polarisation, but the two bacterial species did differ in their potency to induce Th1 cell development.

\section{Discussion}

The combined presence of a biomaterial and bacteria may cause derangements of local immune responses, leading to a BAI. Little is known about the regulation of human $\mathrm{CD}^{+}$Th cells in BAIs, while inadequate Th cell activation and regulation by DCs may be responsible for inadequate cellular responses against bacteria causing BAIs. In this study, an in vitro human cell system was used to study DC and T cell responses to $S$. aureus and S. epidermidis, major causes of BAIs, in the absence and presence of PDLLA and PTMC. It was shown that PDLLA and PTMC had minor effects on immune responses of DCs and T cells to the staphylococci. Although PTMC slightly decreased and, both, PDLLA and PTMC slightly modified $S$. aureus- and S. epidermidis-induced DC marker expression and DC pro-inflammatory cytokine production, respectively, these changes in the DC responses did not affect the DC-induced T cell proliferation or Th1/Th2 cell polarisation. Moreover, $S$. aureus was found to be a more potent inducer of DC cytokine secretion, $\mathrm{T}$ cell proliferation and Th1 cell development than S. epidermidis. Together, 
these observations indicated that PDLLA and PTMC slightly influenced S. aureus- and S. epidermidisinduced DC responses, but that this did not lead to changes in Th cell development.

Polymers such as poly(lactic-co-glycolic acid) (PLGA) and a copolymer of PTMC and poly(L-lactic acid) (LT706 or PLTMC) enhance DC-mediated T cell proliferation or even modulate Th cell polarisation in response to model antigens (Petrizzo et al., 2015; Shokouhi et al., 2010; Yoshida and Babensee, 2004). These immunomodulatory properties of biomaterials are of great interest in shaping the immune response in diverse fields, such as cancer vaccine development, treatments for allergies and treatments for autoimmune diseases. On the other hand, modulation of Th cell responses by biomaterials, resulting in reduced bacterial clearance, can be deleterious. The results of this study showed that neither PDLLA nor PTMC affected the S. aureusor S. epidermidis-induced T cell proliferation or Th1/ Th2 cell development. This suggested that in this human cell model and with these biomaterials, T cell responses were mainly determined by the bacterial species.

In a BAI, staphylococci can reside on the biomaterials in biofilms and they can survive inside or outside macrophages in the tissue surrounding the biomaterial, due to reduced efficacy of the local immune response against the bacteria (Busscher et al., 2012; Zaat et al., 2010). Protection against intracellular survival of staphylococci requires Th1 cell responses. In addition, Th17 cells play an important role in protective immunity against staphylococci (Brown et al., 2015; Milner et al., 2008). In the present study, human naive CD4+ T cells were used to investigate the primary Th cell response to the combination of staphylococci and biomaterials. It was found that $S$. aureus- and S. epidermidis-activated DCs promoted Th1 and Th2 cell development, but they were not capable of promoting Th17 cell development from naive $\mathrm{CD}^{+} \mathrm{T}$ cells in vitro, neither in absence nor in presence of PDLLA or PTMC (data not shown). The requirements for induction of antigen-specific Th17 cell development from truly naive CD4 ${ }^{+} \mathrm{T}$ cells by antigen-presenting cells (APCs) in humans are still under debate, but APCs do promote Th17 cell development from human memory $\mathrm{CD}^{+} \mathrm{T}$ cells (Evans et al., 2007; van Beelen et al., 2007). Since such cells were not used in the current work, this may explain the absence of a Th17 response. However, DCs exposed to the combination of S. epidermidis and PTMC produced larger amounts of the Th17 cell-polarising cytokines IL-6 and IL-23 than DCs exposed to $S$. epidermidis alone. This might indicate the potential of these DCs to induce a Th17 cell response, which might have been observed if memory T cells were included (van Beelen et al., 2007).

Exposure of murine and human DCs to several polymeric biomaterials induces upregulation of DC maturation markers (Babensee and Paranjpe,
2005; Shokouhi et al., 2010). PLTMC, a copolymer containing trimethylene carbonate (TMC) monomers, induces maturation marker expression in murine DCs in vitro (Shokouhi et al., 2010). In contrast, our data showed that exposure of human iDCs to PTMC did not induce upregulation of maturation markers. This difference may be related to the use of DCs from distinct species, since the intensity of the murine DC maturation marker expression in response to a biomaterial may be different from that of human DCs (Yoshida and Babensee, 2004; Yoshida et al., 2007), or to differences in physicochemical properties between PLTMC and PTMC. Although PTMC alone did not affect DC maturation marker expression, PTMC slightly decreased the CD86 expression induced by S. epidermidis (Fig. 1), while T cell activation was not changed. In general, low expression of co-stimulatory molecules is associated with low $\mathrm{T}$ cell activation or with the induction of regulatory $\mathrm{T}$ cells (Nurieva et al., 2010). The lower CD86 expression induced by the combination of PTMC and S. epidermidis was still significantly higher when compared to the expression of these molecules by iDCs. Indeed, despite the lower level of co-stimulatory molecule expression, the stimulated DCs were capable of activating $\mathrm{T}$ cells.

Sensing of biomaterials by DCs is thought to be mediated by DC pattern recognition receptors, such as toll-like receptors (TLRs) and integrins (Rogers and Babensee, 2011; Shokouhi et al., 2010). These receptors may recognise structures in the layer of host proteins, which absorb to the biomaterial surface upon implantation, or may sense the biomaterial surface directly (Rogers and Babensee, 2011; Shokouhi et al., 2010). Variations in the absorbed protein layer depending on biomaterial chemical characteristics such as hydrophobicity, will influence recognition by DC receptors and subsequent DC activation (Shankar et al., 2010). PDLLA and PTMC are both hydrophobic biodegradable polyesters, but PTMC is more flexible, a characteristic which may enhance cell attachment and activation (Evans et al., 2009; Li et al., 2014). Moreover, the degradation products of PDLLA and PTMC may also have different effect on cells. The degradation products of PDLLA are acidic, while the degradation products of PTMC are not (Lu et al., 1999; Zhang et al., 2006). Acidic degradation products can be detrimental to cells and can lead to inflammatory reactions (Yi et al., 2016). In our study, PDLLA and PTMC did not differently affect DC responses in the absence of staphylococci. However, in the presence of staphylococci, these biomaterials did slightly differ in their induction of CD86 expression and IL-23 secretion by DCs. This might indicate that differences in immunomodulating potential of biomaterials might only become evident in the presence of strong immune-stimulators, such as bacteria. Biomaterials might modulate DC responses to bacteria by enabling cross-talk of different DC receptors simultaneously recognising the biomaterial and bacteria. Cross-talk between multiple DC receptors can result in altered 
DC activation (den Dunnen et al., 2012; Mitchell et al., 2010; Re and Strominger, 2004; van Kooyk and Geijtenbeek, 2003). Simultaneous ligation of Fc-gamma-receptor-IIa (Fc $\gamma$ RIIa) and TLR2, 4 or 5 induces a synergistic cytokine response by various APCs (den Dunnen et al., 2012; Vogelpoel et al., 2015), while Fc $\gamma$ RIIa ligation on its own does not lead to a cytokine response. The observation that either PTMC or staphylococci as a single stimulus did not, or only moderately, induce DC cytokine secretion, whereas the combination of both stimuli induced increased levels of cytokines, might suggest a possible similar crosstalk between TLRs recognising bacterial cell envelope components and/ or biomaterial structures and Fc $\gamma$ RIIa recognising antibody-opsonised staphylococci and antibodies absorbed to the PTMC surface. However, blocking DC FC $\gamma$ RIIa did not prevent the increased cytokine production by the DCs stimulated by staphylococci combined with PTMC (data not shown). This result indicated that cross-talk with Fc $\gamma$ RIIa had no role in the increased DC cytokine response observed. Other DC receptors, such as C-type lectins or integrins may be responsible for the modulation of inflammatory cytokine responses.

The increased DCs pro-inflammatory cytokine response to staphylococci in the presence of PTMC and PDLLA may point to non-Th-cell-mediated modulation of the local immune response at the site of infection. Upon recognition of bacteria, DCs, not only initiate adaptive $\mathrm{T}$ cell responses, but also create a local cytokine environment, which attracts and affects other innate immune cells (Lewis and Reizis, 2012). DCs, which stimulate a very strong pro-inflammatory environment, may hyperactivate other phagocytic immune cells, such as monocytes and macrophages; thereby, compromising their intracellular bactericidal function, allowing ingested bacteria to survive (Kanangat et al., 1999). To elucidate multicellular immune responses in BAIs, in vivo animal models or ex vivo human models could be used.

Interestingly, staphylococci-induced DC and T cell responses were not uniform between $S$. aureus and $S$. epidermidis, regardless of the presence of PDLLA or PTMC. S. aureus-stimulated DCs secreted moderately higher levels of pro-inflammatory cytokines than $S$. epidermidis-stimulated DCs. Moreover, S. aureus was a strong inducer of T cell proliferation and Th1 cell development in contrast to S. epidermidis. Consistent with our results, $S$. aureus is shown to be a more potent inducer of IFN and IL-12p70 production by human mononuclear cells than $S$. epidermidis (Buzas et al., 2004). The mechanism underlying the enhanced DC cytokine response to S. aureus is still to be elucidated, but it may be related to the multiple virulence factors expressed by $S$. aureus, such as staphylococcal enterotoxins (Coutant et al., 1999; Stuyt et al., 2001). In addition, staphylococcal enterotoxins likely also play a role in the high $\mathrm{T}$ cell proliferation observed in response to $S$. aureus. These enterotoxins can bypass the need for antigen processing and presentation by directly cross-linking MHC-II molecules on APCs with T cell receptors, triggering activation/proliferation of large numbers of $\mathrm{T}$ cells in an antigen-independent fashion (Spaulding et al., 2013). This strong immune-activating potential of $S$. aureus correlates with more aggressive progression of S. aureus infections as compared with S. epidermidis infections (Subbiahdoss et al., 2011). The differences in intensity of DC and T cell activation between S. aureus and S. epidermidis may, apart from biofilm formation, be an important factor in the pathogenesis of BAIs caused by these bacteria.

\section{Conclusion}

Taken together, our data indicated that PTMC and PDLLA did not interfere with the DC-mediated Th1 and Th2 cell response to $S$. aureus and S. epidermidis. The slightly modified DC inflammatory response to staphylococci in presence of PTMC and PDLLA did not lead to differences in $\mathrm{T}$ cell responses. However, these slightly altered DC responses might affect bacterial clearance in a multicellular setting, e.g. including phagocytic cells such as macrophages. In summary, in designing new biomaterials, it is important to take into account that biomaterials can influence the normal immune response to bacteria and a human cell system, such as the one that was used in this study, is a valuable tool to discern such influences on the human immune response.

\section{Acknowledgements}

We thank Vincent Verdoold of the University of Twente for his technical assistance in the preparation of the biomaterial films. This research did not receive any specific grant from funding agencies in the public, commercial or not-for-profit sectors.

\section{References}

Babensee JE, Paranjpe A (2005) Differential levels of dendritic cell maturation on different biomaterials used in combination products. J Biomed Mater Res A 74: 503-510.

Bat E, van Kooten TG, Feijen J, Grijpma DW (2009) Macrophage-mediated erosion of gamma irradiated poly(trimethylene carbonate) films. Biomaterials 30: 3652-3661.

Beenken KE, Blevins JS, Smeltzer MS (2003) Mutation of sarA in Staphylococcus aureus limits biofilm formation. Infect Immun 71: 4206-4211.

Boelens JJ, Dankert J, Murk JL, Weening JJ, van der Poll T, Dingemans KP, Koole L, Laman JD, Zaat SA (2000a) Biomaterial-associated persistence 
of Staphylococcus epidermidis in pericatheter macrophages. J Infect Dis 181: 1337-1349.

Boelens JJ, van der Poll T, Dankert J, Zaat SA (2000b) Interferon-gamma protects against biomaterial-associated Staphylococcus epidermidis infection in mice. J Infect Dis 181: 1167-1171.

Bosse MJ, Gruber HE, Ramp WK (2005) Internalization of bacteria by osteoblasts in a patient with recurrent, long-term osteomyelitis. A case report. J Bone Joint Surg Am 87: 1343-1347.

Broekhuizen CA, de Boer L, Schipper K, Jones CD, Quadir S, Vandenbroucke-Grauls CM, Zaat SA (2008) Staphylococcus epidermidis is cleared from biomaterial implants but persists in peri-implant tissue in mice despite rifampicin/vancomycin treatment. J Biomed Mater Res A 85: 498-505.

Broekhuizen CA, Sta M, Vandenbroucke-Grauls CM, Zaat SA (2010) Microscopic detection of viable Staphylococcus epidermidis in peri-implant tissue in experimental biomaterial-associated infection, identified by bromodeoxyuridine incorporation. Infect Immun 78: 954-962.

Brown AF, Murphy AG, Lalor SJ, Leech JM, O'Keeffe KM, Mac Aogain M, O'Halloran DP, Lacey KA, Tavakol M, Hearnden CH, Fitzgerald-Hughes D, Humphreys H, Fennell JP, van Wamel WJ, Foster TJ, Geoghegan JA, Lavelle EC, Rogers TR, McLoughlin RM (2015) Memory th1 cells are protective in invasive Staphylococcus aureus infection. PLoS Pathog 11: e1005226.

Busscher HJ, van der Mei HC, Subbiahdoss G, Jutte PC, van den Dungen JJ, Zaat SA, Schultz MJ, Grainger DW (2012) Biomaterial-associated infection: locating the finish line in the race for the surface. Sci Transl Med 4: 153rv110.

Buzas K, Megyeri K, Miczak A, Fekete A, Degre M, Mandi Y, Rosztoczy I (2004) Different staphylococcal strains elicit different levels of production of T-helper 1-inducing cytokines. Acta Microbiol Immunol Hung 51: 371-384.

Christensen GD, Simpson WA, Younger JJ, Baddour LM, Barrett FF, Melton DM, Beachey EH (1985) Adherence of coagulase-negative staphylococci to plastic tissue culture plates: a quantitative model for the adherence of staphylococci to medical devices. J Clin Microbiol 22: 996-1006.

Coutant KD, de Fraissinette AB, Cordier A, Ulrich P (1999) Modulation of the activity of human monocyte-derived dendritic cells by chemical haptens, a metal allergen, and a staphylococcal superantigen. Toxicol Sci 52: 189-198.

Dapunt U, Giese T, Prior B, Gaida MM, Hansch GM (2014) Infectious versus non-infectious loosening of implants: activation of T lymphocytes differentiates between the two entities. Int Orthop 38: 1291-1296.

de Jong EC, Vieira PL, Kalinski P, Schuitemaker JH, Tanaka Y, Wierenga EA, Yazdanbakhsh M, Kapsenberg ML (2002) Microbial compounds selectively induce Th1 cell-promoting or Th2 cellpromoting dendritic cells in vitro with diverse th cell-polarizing signals. J Immunol 168: 1704-1709. den Dunnen J, Vogelpoel LT, Wypych T, Muller FJ, de Boer L, Kuijpers TW, Zaat SA, Kapsenberg ML, de Jong EC (2012) IgG opsonization of bacteria promotes Th17 responses via synergy between TLRs and FcgammaRIIa in human dendritic cells. Blood 120: 112-121.

Donlan RM, Costerton JW (2002) Biofilms: survival mechanisms of clinically relevant microorganisms. Clin Microbiol Rev 15: 167-193.

Evans HG, Suddason T, Jackson I, Taams LS, Lord GM (2007) Optimal induction of T helper 17 cells in humans requires $\mathrm{T}$ cell receptor ligation in the context of Toll-like receptor-activated monocytes. Proc Natl Acad Sci U S A 104: 17034-17039.

Evans ND, Minelli C, Gentleman E, LaPointe V, Patankar SN, Kallivretaki M, Chen X, Roberts CJ, Stevens MM (2009) Substrate stiffness affects early differentiation events in embryonic stem cells. Eur Cell Mater 18: 1-14.

Gandelman G, Frishman WH, Wiese C, GreenGastwirth V, Hong S, Aronow WS, Horowitz HW (2007) Intravascular device infections: epidemiology, diagnosis, and management. Cardiol Rev 15: 13-23.

Henke PK, Bergamini TM, Brittian KR, Polk HC, Jr. (1997) Prostaglandin E2 modulates monocyte MHC-II (Ia) suppression in biomaterial infection. J Surg Res 69: 372-378.

Kanangat S, Meduri GU, Tolley EA, Patterson DR, Meduri CU, Pak C, Griffin JP, Bronze MS, Schaberg DR (1999) Effects of cytokines and endotoxin on the intracellular growth of bacteria. Infect Immun 67: 2834-2840.

Kubica M, Guzik K, Koziel J, Zarebski M, Richter W, Gajkowska B, Golda A, Maciag-Gudowska A, Brix K, Shaw L, Foster T, Potempa J (2008) A potential new pathway for Staphylococcus aureus dissemination: the silent survival of $S$. aureus phagocytosed by human monocyte-derived macrophages. PLoS One 3: e1409.

Lewis KL, Reizis B (2012) Dendritic cells: arbiters of immunity and immunological tolerance. Cold Spring Harb Perspect Biol 4: a007401.

Li X, Huang Y, Zheng L, Liu H, Niu X, Huang J, Zhao F, Fan Y (2014) Effect of substrate stiffness on the functions of rat bone marrow and adipose tissue derived mesenchymal stem cells in vitro. J Biomed Mater Res A 102: 1092-1101.

Lu L, Garcia CA, Mikos AG (1999) In vitro degradation of thin poly(DL-lactic-co-glycolic acid) films. J Biomed Mater Res 46: 236-244.

Milner JD, Brenchley JM, Laurence A, Freeman AF, Hill BJ, Elias KM, Kanno Y, Spalding C, Elloumi HZ, Paulson ML, Davis J, Hsu A, Asher AI, O'Shea J, Holland SM, Paul WE, Douek DC (2008) Impaired $\mathrm{T}(\mathrm{H}) 17$ cell differentiation in subjects with autosomal dominant hyper-IgE syndrome. Nature 452: 773-776.

Mitchell D, Yong M, Schroder W, Black M, Tirrell M, Olive C (2010) Dual stimulation of MyD88dependent Toll-like receptors induces synergistically enhanced production of inflammatory cytokines in murine bone marrow-derived dendritic cells. J Infect Dis 202: 318-329. 
Nurieva R, Thomas S, Nguyen T, Martin-Orozco N, Wang Y, Murali-Krishna K, Yu X-Z, Dong C (2006) T-cell tolerance or function is determined by combinatorial costimulatory signals. EMBO J 25: 2623-2633.

Pego AP, Van Luyn MJ, Brouwer LA, van Wachem PB, Poot AA, Grijpma DW, Feijen J (2003) In vivo behavior of poly(1,3-trimethylene carbonate) and copolymers of 1,3-trimethylene carbonate with D,Llactide or epsilon-caprolactone: degradation and tissue response. J Biomed Mater Res A 67: 1044-1054.

Petrizzo A, Conte C, Tagliamonte M, Napolitano M, Bifulco K, Carriero V, De Stradis A, Tornesello ML, Buonaguro FM, Quaglia F, Buonaguro L (2015) Functional characterization of biodegradable nanoparticles as antigen delivery system. J Exp Clin Cancer Res 34: 114.

Prabhakara R, Harro JM, Leid JG, Keegan AD, Prior ML, Shirtliff ME (2011) Suppression of the inflammatory immune response prevents the development of chronic biofilm infection due to methicillin-resistant Staphylococcus aureus. Infect Immun 79: 5010-5018.

Re F, Strominger JL (2004) IL-10 released by concomitant TLR2 stimulation blocks the induction of a subset of Th1 cytokines that are specifically induced by TLR4 or TLR3 in human dendritic cells. J Immunol 173: 7548-7555.

Rochford ET, Sabate Bresco M, Zeiter S, Kluge K, Poulsson A, Ziegler M, Richards RG, O'Mahony L, Moriarty TF (2016) Monitoring immune responses in a mouse model of fracture fixation with and without Staphylococcus aureus osteomyelitis. Bone 83: 82-92.

Rogers TH, Babensee JE (2011) The role of integrins in the recognition and response of dendritic cells to biomaterials. Biomaterials 32: 1270-1279.

Sallusto F, Lanzavecchia A (1994) Efficient presentation of soluble antigen by cultured human dendritic cells is maintained by granulocyte/ macrophage colony-stimulating factor plus interleukin 4 and downregulated by tumor necrosis factor alpha. J Exp Med 179: 1109-1118.

Schakenraad JM, Nieuwenhuis P, Molenaar I, Helder J, Dijkstra PJ, Feijen J (1989) In vivo and in vitro degradation of glycine/DL-lactic acid copolymers. J Biomed Mater Res 23: 1271-1288.

Shankar SP, Petrie TA, Garcia AJ, Babensee JE (2010) Dendritic cell responses to self-assembled monolayers of defined chemistries. J Biomed Mater Res A 92: 1487-1499.

Shokouhi B, Coban C, Hasirci V, Aydin E, Dhanasingh A, Shi N, Koyama S, Akira S, Zenke M, Sechi AS (2010) The role of multiple toll-like receptor signalling cascades on interactions between biomedical polymers and dendritic cells. Biomaterials 31: 5759-5771.

Smith RP, Baltch AL, Ritz WJ, Michelsen PB, Bopp LH (2010) IFN-gamma enhances killing of methicillinresistant Staphylococcus aureus by human monocytes more effectively than GM-CSF in the presence of daptomycin and other antibiotics. Cytokine 51: 274277.

Spaulding AR, Salgado-Pabon W, Kohler PL, Horswill AR, Leung DY, Schlievert PM (2013) Staphylococcal and streptococcal superantigen exotoxins. Clin Microbiol Rev 26: 422-447.

Stewart PS, Costerton JW (2001) Antibiotic resistance of bacteria in biofilms. Lancet 358: 135-138.

Stuyt RJ, Netea MG, Kim SH, Novick D, Rubinstein M, Kullberg BJ, Van der Meer JW, Dinarello CA (2001) Differential roles of interleukin-18 (IL-18) and IL12 for induction of gamma interferon by staphylococcal cell wall components and superantigens. Infect Immun 69: 5025-5030.

Subbiahdoss G, Fernandez IC, Domingues JF, Kuijer R, van der Mei HC, Busscher HJ (2011) In vitro interactions between bacteria, osteoblast-like cells and macrophages in the pathogenesis of biomaterialassociated infections. PLoS One 6: e24827.

van Beelen AJ, Zelinkova Z, Taanman-Kueter EW, Muller FJ, Hommes DW, Zaat SA, Kapsenberg ML, de Jong EC (2007) Stimulation of the intracellular bacterial sensor NOD2 programs dendritic cells to promote interleukin-17 production in human memory T cells. Immunity 27: 660-669.

van der Aar AM, Sibiryak DS, Bakdash G, van Capel TM, van der Kleij HP, Opstelten DJ, Teunissen MB, Kapsenberg ML, de Jong EC (2011) Vitamin D3 targets epidermal and dermal dendritic cells for induction of distinct regulatory T cells. J Allergy Clin Immunol 127: 1532-1540 e1537.

van Kooyk Y, Geijtenbeek TB (2003) DC-SIGN: escape mechanism for pathogens. Nat Rev Immunol 3: 697-709.

Vogelpoel LT, Hansen IS, Visser MW, Nagelkerke SQ, Kuijpers TW, Kapsenberg ML, de Jong EC, den Dunnen J (2015) Fc $\gamma$ RIIa cross-talk with TLRs, IL-1R, and IFN $\gamma R$ selectively modulates cytokine production in human myeloid cells. Immunobiology 220: 193-199.

Vuong C, Otto M (2002) Staphylococcus epidermidis infections. Microbes Infect 4: 481-489.

Wagner C, Heck D, Lautenschlager K, Iking-Konert C, Heppert V, Wentzensen A, Hansch GM (2006) T lymphocytes in implant-associated posttraumatic osteomyelitis: identification of cytotoxic T effector cells at the site of infection. Shock 25: 241-246.

Yi J, Xiong F, Li B, Chen H, Yin Y, Dai H, Li S (2016) Degradation characteristics, cell viability and host tissue responses of PDLLA-based scaffold with PRGD and beta-TCP nanoparticles incorporation. Regen Biomater 3: 159-166.

Yoshida M, Babensee JE (2004) Poly(lacticco-glycolic acid) enhances maturation of human monocyte-derived dendritic cells. J Biomed Mater Res A 71: 45-54.

Yoshida M, Mata J, Babensee JE (2007) Effect of poly(lactic-co-glycolic acid) contact on maturation of murine bone marrow-derived dendritic cells. J Biomed Mater Res A 80: 7-12. 
Zaat S, Broekhuizen C, Riool M (2010) Host tissue as a niche for biomaterial-associated infection. Future Microbiol 5: 1149-1151.

Zhang Z, Kuijer R, Bulstra SK, Grijpma DW, Feijen $\mathrm{J}$ (2006) The in vivo and in vitro degradation behavior of poly(trimethylene carbonate). Biomaterials 27: 1741-1748.

Zimmerli W, Lew PD, Waldvogel FA (1984) Pathogenesis of foreign body infection. Evidence for a local granulocyte defect. J Clin Invest 73: 1191-1200.

Zimmerli W, Sendi P (2011) Pathogenesis of implant-associated infection: the role of the host. Semin Immunopathol 33: 295-306.
Zimmerli W, Trampuz A, Ochsner PE (2004) Prosthetic-joint infections. N Engl J Med 351: 16451654.

Editor's note: All of the matters raised by the reviewers have been incorporated in the main text, so there is no Discussion with Reviewers section for this paper.

The Scientific Editor responsible for this paper was Fintan Moriarty. 